\title{
Threatened birds of Guatemala: a random subset of the avifauna?
}

\author{
ANDREA NÁJERA and JAVIER A. SIMONETTI
}

\section{Summary}

Identifying attributes that affect the vulnerability of a species to extinction is important as it allows conservation efforts to be focused on more susceptible species. We assessed whether threatened birds of Guatemala are a random subset of the avifauna, considering their taxonomic affiliation, body size, diet and geographical distribution. We found that threatened bird species in Guatemala were neither taxonomically nor geographically randomly distributed. Large-bodied species and Psittaciformes, Galliformes, Falconiformes and Ciconiformes were among the most threatened groups, and the Pacific slopes of the country hosted more threatened birds than would be expected. Published scientific information regarding Critically Endangered bird species in Guatemala is scant and biased against nocturnal and aquatic species. Research and conservation efforts ought to be oriented toward these species and regions to safeguard the Guatemalan avifauna. This study allows an overall consideration on whether we are conserving the species and areas that are important for threatened birds.

\section{Resumen}

La identificación de los atributos que afectan la vulnerabilidad a la extinción en las especies permite focalizar los esfuerzos de conservación en las especies más susceptibles. Nosotros evaluamos si las aves amenazadas de Guatemala son un subconjunto aleatorio de su avifauna, en relación a su afiliación taxonómica, tamaño corporal, dieta y distribución geográfica. Las especies de aves amenazadas en Guatemala no están ni taxonómica ni geográficamente distribuidas al azar. Las especies con mayor tamaño corporal, y los Psittaciformes, Galliformes, Falconiformes y Ciconiformes son los grupos más amenazados, y las laderas del Pacífico albergan más especies de aves amenazadas de lo que se esperaría por simple azar. La información científica publicada respecto las especies críticamente amenazadas en Guatemala es escasa y sesgada contra especies acuáticas y nocturnas. Los esfuerzos de investigación y conservación deberían ser orientados hacia estas especies y regiones para proteger la avifauna de Guatemala. Este estudio permite una reflexión global sobre si estamos conservando las especies y las áreas que son importantes para las aves amenazadas.

\section{Introduction}

Extinction risk does not affect all bird species equally, some groups being more or less susceptible (Russell et al. 1998, Owens and Bennett 2000). It is necessary to understand the factors that determine whether a species is threatened in order to properly focus conservation efforts on more susceptible species (e.g. Carter et al. 2000). Biological attributes such as body size, diet and habitat use might interact with external factors such as habitat loss or hunting, rendering some species more susceptible to threats than others (Owens and Bennett 2000).

The avifauna of Guatemala is severely threatened. In 30 out of 77 bird families found in Guatemala, $60 \%$ or more of the species are threatened. At the species level, $46 \%$ (223) out of 
484 resident bird species are regarded as threatened (Eisermann and Avendaño 2006a). Habitat loss is considered the main threat to birds (IUCN 2008). To be cost-effective, conservation actions need to prioritise taxa and geographic areas that are particularly vulnerable (e.g. Rodriguez et al. 2004, Carwardine et al. 2008).

Here, we explore whether the threatened birds of Guatemala are a random subset of the avifauna, considering their taxonomic affiliation, body size, diet and geographic distribution, factors that can impinge upon proneness to extinction (Gaston and Blackburn 1995). If threats are randomly distributed, orders containing more species should hold more threatened species compared with those that are species-poor. Further, threatened species should be randomly distributed across the range of body size and diets, proportional to the species richness for each size and diet class. Similarly, biomes covering larger areas, and thus supporting richer bird assemblages, should hold more threatened species than geographically-restricted biomes that are comparatively poor in species. Departures from randomness will allow taxa, species groups, or biomes that might require special conservation attention to be identified.

\section{Methods}

To test departures from randomness, we compared whether the observed frequency of threatened species per order, body size, diet class and geographic area, differed from the expected frequency, assuming that the proportion of threatened species would be evenly distributed across these gradients or classes (Kattan 1994). We classified each of the 484 resident bird species according to their taxonomic affiliation to family and order level (Howell and Webb 1995), average body size, diet and IUCN Red List criteria applied on a national level (Eisermann and Avendaño 2006a), as well as their presence in the seven recognised biomes of Guatemala (Eisermann and Avendaño 2006a, Howell and Webb 1995, Villar 1994).

To analyse whether threats are randomly distributed across taxonomic affiliation, we tested if the number of threatened species per order differs from what would be expected by chance. For the $\chi^{2}$ test, some orders were pooled to obtain expected values greater than 5 . As $46 \%$ of this fauna is regarded as threatened, if threats are randomly distributed across taxa, we would expect $46 \%$ of the species of each order to be listed as threatened. Similarly, we tested whether the proportion of threatened birds differs among body size and diet categories (carnivores, frugivores, frugivoresinsectivores, granivores, granivores-frugivores, insectivores, nectarivores, omnivores). Body size and diets were obtained from Howell and Webb (1995).

To assess whether threatened species are randomly distributed across Guatemala, we estimated the percentage of the country's area occupied by each biome and quantified the number of threatened species per threat category (Vulnerable, Endangered, Critically Endangered) occurring in each one. The number of threatened species per biome was compared to the expected number of threatened species based on the proportion of the total avifauna supported for each biome.

\section{Results}

Species vulnerability is associated with taxonomic affiliation $\left(\chi_{13}^{2}=37.1 ; P<0.0004\right.$; Table 1$)$. A greater proportion of Psittaciformes, Galliformes, Falconiformes and Ciconiformes were threatened than would be expected by chance, while fewer than expected Passeriformes were threatened (heterogeneity $\chi_{10}^{2}=15.40 ; P=0.118$ ). All 15 Psittaciformes species are threatened, while $79 \%$ of Galliformes, $72 \%$ of Ciconiformes and $71 \%$ of Falconiformes species are regarded of conservation concern (Table 2). Threatened species were larger than those regarded as of least concern $\left(F_{3}=13.73 ; P<\right.$ o.001). Average body size (in $\mathrm{cm}$; mean $\pm \mathrm{SD}$ ) of resident threatened Guatemalan birds differs across IUCN categories. 'Least Concern' species averaged $23.8 \pm 12.4$, 'Vulnerable' species $27.4 \pm 19.0$, 'Endangered' species $36.7 \pm 22.1$ and 'Critically Endangered' species $55.9 \pm 34.4$. On average, 'Critically Endangered' species are 2.4 times larger than species of 'Least Concern', and significantly different from all other categories $(P<0.02$ in all cases, 
Table 1. Number of threatened bird species in Guatemala. Figures are the observed and expected number per taxonomic orders. Some taxa were grouped in order to attain the requirements of the $\chi^{2}$ proof that does not permit expected numbers smaller than 5 .

\begin{tabular}{lc}
\hline ORDER & Observed (expected) \\
\hline $\begin{array}{l}\text { Podicipediformes, Pelecaniformes, Anseriformes } \\
\quad \text { and Charadriformes }\end{array}$ & $9(5.5)$ \\
Caprimulgiformes and Cuculiformes & $6(7.3)$ \\
Tinamiformes and Trogoniformes & $7(5.0)$ \\
Strigiformes & $10(7.8)$ \\
Piciformes & $11(7.8)$ \\
Passeriformes & $88(112.8)$ \\
Apodiformes & $9(19.8)$ \\
Ciconiformes & $13(8.2)$ \\
Coraciformes & $5(5.0)$ \\
Falconiformes & $24(15.6)$ \\
Galliformes & $11(6.4)$ \\
Gruiformes & $8(5.9)$ \\
Columbiformes & $7(8.2)$ \\
Psittaciformes & $15(6.9)$ \\
Total & 223 \\
\hline
\end{tabular}

unequal N HSD test). Large-bodied species are persecuted for trade and have low reproductive rates which might account for their higher degree of threat (Owens and Bennett 2000). In fact, large bodies are a common attribute of threatened Neotropical birds (Kattan 1992, 1994), indicating that larger species might need special attention. Further, the proportion of species under threat is also related to food habits $\left(\chi_{7}^{2}=15.96 ; P=0.02\right)$. The proportion of carnivorous species under threat was 1.35 times higher than expected by random. The frequency of other trophic groups did not differ from that expected by a random distribution (heterogeneity $\chi_{6}^{2}=11.19$; $P=0.08$ ).

Threatened species tended to be concentrated in particular areas $\left(\chi_{4}^{2}=579.4 ; P<0.001\right)$. The Subtropical Humid Forest, located on the Pacific slope, contains 7.6 times more threatened species than would be expected according to its area (Table 3). This biome supports $32 \%$ of the threatened species in an area equivalent to only $4.2 \%$ of Guatemalan territory.

In summary, threatened Guatemalan birds are not a random subset of the country's avifauna, as threatened species are neither taxonomically nor geographically randomly distributed. Largebodied species and Orders such as Psittaciformes, Galliformes, Falconiformes and Ciconiformes are among the groups with the highest proportion of threatened species, and the Pacific slope is a key area for threatened bird conservation.

\section{Discussion}

Effective conservation plans need to be supported by scientific and technical information (Pullin et al. 2004). Information regarding threatened Guatemalan birds is scant at best (see Appendix I in Eisermann and Avendaño 2006a). The number of published scientific papers per species within families containing 'Critically Endangered' species does not differ from that for less threatened and non-threatened species ( 1.8 vs 1.7 papers respectively; $z=-0.37 ; P=0.36$ ). According to the list by Eisermann and Avendaño (2006b) there are no Guatemalan publications available on the conservation of 'Critically Endangered' Anatidae, Rallidae and Strigidae or Sunbittern Eurypyga helias, the single species of the Eurypygidae. An evaluation of waterbird populations in Guatemala (Eisermann and Avendaño 2006b) reveals that data are deficient for understanding population sizes and trends of 'Critically Endangered' waterbirds such as Pardirallus maculatus. 
Table 2. Number of threatened bird species of Guatemala according to IUCN categories applied to the country. Figures are for the 30 bird families that have $60 \%$ or more of their species threatened (after Eisermann and Avendaño 2006a).

\begin{tabular}{|c|c|c|c|c|c|c|}
\hline FAMILY & CR & EN & VU & NT & LC & $\begin{array}{l}\% \text { of the family } \\
\text { threatened }\end{array}$ \\
\hline Accipitridae & 3 & 3 & 14 & 4 & 3 & 74.1 \\
\hline Anatidae & 2 & & 2 & & & 100 \\
\hline Psittacidae & 2 & & 13 & & & 100 \\
\hline Momotidae & 2 & & 3 & & 2 & 71.4 \\
\hline Odontophoridae & 1 & 1 & 4 & 1 & & 85.7 \\
\hline Strigidae & 1 & 1 & 8 & 4 & 2 & 62.5 \\
\hline Ciconidae & 1 & & 1 & & & 100 \\
\hline Euripigidae & 1 & & & & & 100 \\
\hline Nyctibidae & & 1 & 1 & & & 100 \\
\hline Ardeidae & & 1 & 10 & & 1 & 91.7 \\
\hline Parulidae & & 1 & 9 & 3 & 2 & 66.7 \\
\hline Cracidae & & 1 & 3 & 2 & & 66.7 \\
\hline Dendrocolaptidae & & & 12 & & & 100 \\
\hline Ramphastidae & & & 3 & & & 100 \\
\hline Buconidae & & & 2 & & & 100 \\
\hline Formicaridae & & & 2 & & & 100 \\
\hline Phasianidae & & & 1 & & & 100 \\
\hline Galbulidae & & & 1 & & & 100 \\
\hline Pelecanidae & & & 1 & & & 100 \\
\hline Burhinidae & & & 1 & & & 100 \\
\hline Recurvirostridae & & & 1 & & & 100 \\
\hline Charadriidae & & & 1 & & & 100 \\
\hline Heliornitidae & & & 1 & & & 100 \\
\hline Certhidae & & & 1 & & & 100 \\
\hline Peucedramidae & & & 1 & & & 100 \\
\hline Cotingidae & & & 1 & & & 100 \\
\hline Regulidae & & & 1 & & & 100 \\
\hline Aramidae & & & 1 & & & 100 \\
\hline Trogonidae & & & 5 & 2 & & 71.4 \\
\hline Furnaridae & & & 5 & 1 & 1 & 71.4 \\
\hline
\end{tabular}

Publications on Black-throated Bobwhite Colinus nigrogularis, a 'Critically Endangered' quail, are limited to the description of a new subspecies in 1932, and two reports in 1935 and 1955; since then, no other information has been gathered (Eisermann and Avendaño 2009). Even within taxa, information is skewed. For instance, for the two 'Critically Endangered' Psittacidae species, 13 out of 18 published papers are available for Scarlet Macaw Ara macao contrasting with just five devoted to Yellow-headed Amazon Amazona oratrix (see Appendix 1 in Eisermann and Avendaño 2006a, for the full bibliography on Guatemalan birds from 1577 to 2004). The paucity of information highlights a clear need for research focused on the most susceptible and threatened taxa.

Geographically, the Pacific slopes region (Subtropical Humid Forest) should be a prime target for conservation efforts. Although all species found there can be also found in other biomes, mainly in the Atlantic region and Guatemala's highlands, conservation efforts ought to be increased in the Pacific slopes as protected areas cover just 227 ha of this biome, compared to 325,000 ha formally protected in the Atlantic region (Tropical humid and rainforest biomes; CONAP 2006). Guatemala has 297 official protected areas, and new areas are being established, including a growing number of private reserves (CONAP 2010b). Based on a gap analysis, the Guatemalan western volcanic chain, which includes the Pacific slopes, has been recently identified 
Table 3. Threatened bird species by biogeographic regions of Guatemala. Figures are the observed and the expected number of species (Observed number of species according to Eisermann and Avendaño 2006a)

\begin{tabular}{|c|c|c|c|c|}
\hline Region & Biome in the region (approx) & $\begin{array}{l}\% \text { of the } \\
\text { country that } \\
\text { it occupies }\end{array}$ & $\begin{array}{l}\text { Observed } \\
\text { threatened } \\
\text { species ( } \% \text { of the } \\
\text { total threatened) }\end{array}$ & $\begin{array}{l}\text { Expected } \\
\text { threatened } \\
\text { species for such } \\
\text { an area }\end{array}$ \\
\hline $\begin{array}{l}\text { Atlantic lowlands and } \\
\text { Atlantic slopes }\end{array}$ & $\begin{array}{l}\text { Tropical humid forest, tropical } \\
\text { rainforest and pine savanna }\end{array}$ & 52.4 & $161(72.2)$ & 116.7 \\
\hline Highlands & $\begin{array}{l}\text { Mountain broadleaf forest and } \\
\text { mountain conifer forest }\end{array}$ & 26.4 & $102(45 \cdot 7)$ & 58.8 \\
\hline Pacific slopes & Subtropical humid forest & 4.2 & $73(32.7)$ & $9 \cdot 3$ \\
\hline Pacific lowlands & Tropical humid savanna & 10.9 & $71(31.83)$ & $24 \cdot 4$ \\
\hline Interior valleys & Thorn scrub & 6.1 & $22(9.86)$ & 13.4 \\
\hline
\end{tabular}

as a priority area for conservation (CONAP 2010a). Our results offer support for this decision. Further, some private protected areas are being established in the Pacific slopes region, offering specialised bird-watching tours, contributing to protection of the threatened avifauna. Besides the native forest contained mainly in these protected areas, the Pacific slopes are also largely covered with coffee and coffee-cardamom plantations (MAGA 2006). These agroforestry systems, together with the public and private protected areas, can contribute to the conservation of local biodiversity, since shade-coffee plantations are capable of holding an important fraction of the original species from native forests, due to the structural and floristic diversity given by the canopy of shade trees (Perfecto et al. 2005; see also Nájera and Simonetti 2010). Given that the additional area added to the Guatemalan protected areas system is getting progressively smaller, and the likelihood of protecting larger areas - in Guatemala, and worldwide - seems low (IARNA 2006), biodiversity conservation ought to be attempted in productive landscapes outside protected areas (e.g. Perfecto and Vandermeer 2008), particularly in biomes where agricultural activities are high or increasing, such as the Pacific slopes in Guatemala. In order to protect its avifauna, Guatemala ought to focus on threatened taxa and biomes that currently do not receive the attention required.

\section{Acknowledgements}

Andrea Nájera was an AGCI fellowship holder (Agencia de Cooperacion Internacional de Chile).

\section{References}

Carter, M. F., Hunter, W. C., Pasley, D. N. and Rosenberg, K. (2000) Setting conservation priorities for landbirds in the United States: the Partners in Flight approach. Auk 117: $541-548$.

Carwardine, J., Wilson, K. A., Ceballos, G., Ehrlich, P. R., Naido, R., Iwamura, T., Hajkowicz, S. A., Possingham, H. P. and Carwardine, J. (2008) Cost-effective priorities for global mammal conservation. Proc. Natl. Ac. Sci. USA 105: 11446-11450.

CONAP - Consejo Nacional de Áreas Protegidas (2006) Sistema guatemalteco de áreas
protegidas-SIGAP. Listado y mapa de áreas protegidas inscritas en el SIGAP. Guatemala: Consejo Nacional de Áreas Protegidas.

CONAP - Consejo Nacional de Áreas Protegidas (2010a) Conservación de la biodiversidad terrestre de Guatemala: análisis de vacíos y estrategias para su conservación. Guatemala: TNC- WWF-CI-CONAP.

CONAP - Consejo Nacional de Áreas Protegidas (2010b) Sistema guatemalteco de áreas protegidas-SIGAP. Listado público de áreas protegidas inscritas en el SIGAP. 
http://www.conap.gob.gt/biodiversidad/ sigap (accessed 10 May 2011).

Eisermann, K. and Avendaño, C. (2006a) Diversidad de aves en Guatemala, con una lista bibliográfica. Pp. 525-623 in E. Cano, ed. Biodiversidad de Guatemala, Vol. 1. Guatemala: Universidad del Valle de Guatemala.

Eisermann, K. and Avendaño, C. (2006b) Evaluation of waterbirds populations and their conservation in Guatemala. Guatemala: Sociedad Guatemalteca de Ornitología.

Eisermann, K. and Avendaño, C. (2009) Conservation priority-setting in Guatemala through the identification of important bird areas. Proc. Fourth International Patterns in Flight Conference: Tundra to tropics: 315-327.

Gaston, K. J. and Blackburn, T. M. (1995) Birds, body size, and the threat of extinction. Phil. Trans. R. Soc. London Biol. Sci. 347: 205-212.

Howell, S. N. G. and Webb, S. (1995) A guide to the birds of Mexico and Northern Central America. Oxford, UK: Oxford University Press.

IARNA (2006) Perfil ambiental de Guatemala: tendencias y reflexiones sobre la gestión ambiental. Guatemala: Instituto de Agricultura, Recursos Naturales y Ambiente, Universidad Rafael Landívar (URL) and Instituto de Incidencia Ambiental (IIA).

IUCN (2008) The IUCN Red List of threatened species. www.iucnredlist.org accessed 6 January 2008.

Kattan, G. H. (1992) Rarity and vulnerability: the birds of the Cordillera Central of Colombia. Conserv. Biol. 6: 64-70.

Kattan, G. (1994) Forest fragmentation and bird extinctions: San Antonio eighty years later. Conserv. Biol. 8: 138-146.
MAGA (2006) Mapa de cobertura vegetal y uso de la tierra, República de Guatemala. Guatemala: Ministerio de Agricultura, Ganadería y Alimentación.

Nájera, A. and Simonetti, J. A. (2010) Enhancing avifauna in commercial plantations. Conserv. Biol. 24: 319-324.

Owens, I. P. F. and Bennett, P. M. (200o) Ecological basis of extinction risk in birds: Habitat loss versus human persecution and introduced predators. Proc. Natl. Ac. Sci. 97: 2144-2148.

Perfecto, I., Vandermeer, J., Mas, A. and Soto, L. (2005) Biodiversity, yield and shade coffee certification. Ecol. Econ. 54: 435-446.

Perfecto, I. and Vandermeer, J. (2008) Biodiversity conservation in tropical agroecosystems; a new conservation paradigm. Ann. New York Ac. Sci. 1134: 173-200.

Pullin, A. S., Knight, T. M., Stone, D. A. and Charman, K. (2004) Do conservation managers use scientific evidence to support their decision-making? Biol. Conserv. 119: 245-252.

Russell, G. J., Brooks, T. M., McKinney, M. M. and Anderson, C. G. (1998) Present and future taxonomic selectivity in bird and mammal extinctions. Conserv. Biol. 12: $1365-1376$.

Rodriguez, J. P., Rojas-Suárez, F. and Sharpe, C. J. (2004) Setting priorities for the conservation of Venezuela's endangered birds. Oryx 38: 373-382.

Villar, L. (1994) Informe de País, Guatemala. Perfil General. Pp. 193-221 In A. Vargas, ed. Corredores conservacionistas de la región Centroamericana. Gainsesville, FL, USA: Tropical Research and Development Inc.

\section{ANDREA NÁJERA, JAVIER A. SIMONETTI*}

Departamento de Ciencias Ecológicas, Facultad de Ciencias, Universidad de Chile P.O. Box 653, Santiago, Chile.

*Author for correspondence; e-mail: jsimonet@uchile.cl

Received 29 December 2010; revision accepted 23 August 2011; Published online 16 December 2011 